\title{
Videogame e museo. La rappresentazione dello spazio come strumento narrativo per il patrimonio culturale
}

\author{
Greta Attademo
}

Abstract

Nel nostro secolo, la ludicizzazione della comunicazione e l'avvento di nuovi media, di cui il videogame è l'emblema, hanno prodotto un cambio di paradigma nelle modalità di conoscenza e di esperienza dell'uomo sul mondo, invitando a riflettere sul ruolo della rappresentazione nella ridefinizione dei rapporti tra società, immagini e narrazione. Essa infatti, che ha da sempre costituito un codice comunicativo universale, incardinando significati complessi in un sistema visivo di segni, viene oggi adoperata anche dai musei come linguaggio narrativo per rendere più fruibile il proprio patrimonio. II suo impiego, tuttavia, è spesso limitato alla realizzazione di spettacolari immagini potenziate dalle nuove tecnologie, piuttosto che orientato alle sue capacità comunicative. La presente ricerca, pertanto, indaga la rappresentazione come possibile strategia narrativa nel videogame. Analizzando i fattori distintivi del nuovo medium, emerge il ruolo centrale della rappresentazione dello spazio come strumento in grado di implementare la narrazione sottesa al gioco. La comparazione tra il videogame esperienziale 'What Remains of Edith Finch' e il videogame culturale The Medici Game. Murder at Pitti Palace, rivela elementi e modalità con cui l'immagine dello spazio può intervenire sulla narrazione, stimolando la conoscenza del patrimonio culturale e creando, così, una connessione tra i linguaggi aperti del videogame e il ruolo odierno del museo di ambiente di apprendimento informale.

Parole chiave

videogame culturale, museo, spazio narrativo, ludicizzazione, patrimonio culturale.

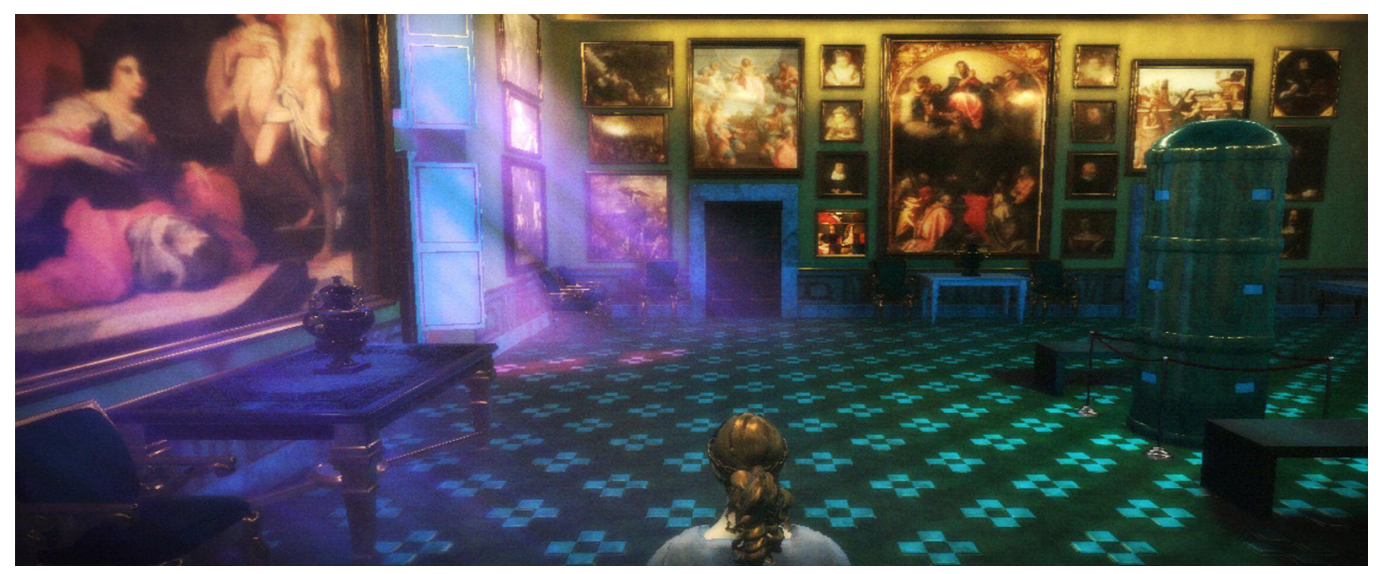




\section{Introduzione}

II ruolo pervasivo dei giochi nella nostra epoca ha portato gli studiosi a parlare non solo di un "ludic century" [Chaplin, Zimmerman 2013] ma di un "ludic turn" [Murray 2006], un momento di svolta che, grazie all'avvento dei nuovi media, ha sistematicamente trasformato la struttura dell'informazione con approcci più giocosi e creativi, portando ad un cambio di paradigma nelle modalità di conoscenza e di esperienza dell'uomo sul mondo. In effetti i videogames, emblema del nostro tempo, "non sono solo un fenomeno sociale, essi rappresentano il punto di convergenza essenziale per una ridefinizione della nostra relazione con il mondo della narrazione per immagini" [Higuinen, Tesson 2002, p. 5]; la loro capacità di generare modalità narrative diverse dagli altri media li rende, infatti, portavoce di nuovi significati per la rappresentazione. Quest'ultima è stata, nel corso dei secoli, importante mezzo di comunicazione tra esperti e collettività quando rivelativa non di una generica realtà, ma della percezione della realtà in cui si andava affermando [Maldonado 2015]; quando, cioè, il suo ruolo di strumento di trascrizione della realtà visibile - connaturato già nella stessa radice 'idein/vedere' delle parole 'eidos/idea' ed 'eidolon/immagine' - mediava tra vedere sensibile e vedere intellegibile. Non è un caso che nella società odierna, in cui il concetto di cultura dell'informazione è parallelo al concetto di cultura visiva [Manovich 2005, p. 39], anche le istituzioni museali adoperino la rappresentazione come strategia narrativa per rendere più fruibile il proprio patrimonio, considerando anche che l'utenza culturale, costituita sia da 'immigrati digitali' che da 'nativi digitali' [Prensky 2013], necessiti di differenti modalità comunicative per recepire quelle tracce, insite nei beni stessi, che altrimenti rischierebbero "di rimanere mute in assenza di soggetti in grado di percepirle e interpretarle" [Toscano, Gremigni 2008, p. |45]. Alcuni luoghi culturali, tuttavia, hanno limitato le potenzialità della rappresentazione alla spettacolarizzazione delle immagini, piuttosto che evidenziarne le capacità interpretative; la componente digitale è stata intesa come garante esclusiva di una corretta comunicazione, senza considerare che la "mole informativa invisibile che ogni oggetto veicola di per se stesso al di là della mera dimensione materica" [Bergamo, Bortot, Boscaro et al. 2016, p. 3] acquista senso solo se trasmessa tramite un'azione culturale in cui la comunità può riconoscersi [Salvarani 2005]. Partendo dall'idea dell'immagine statica come simbolo della contemplazione passiva tipica del museo del secolo scorso, la ricerca propone di indagare il videogioco, nella sua duplice essenza di immagine e azione, come possibile chiave di lettura del museo contemporaneo, inteso come detentore di storie, più che di opere o reperti [Beale 20II].
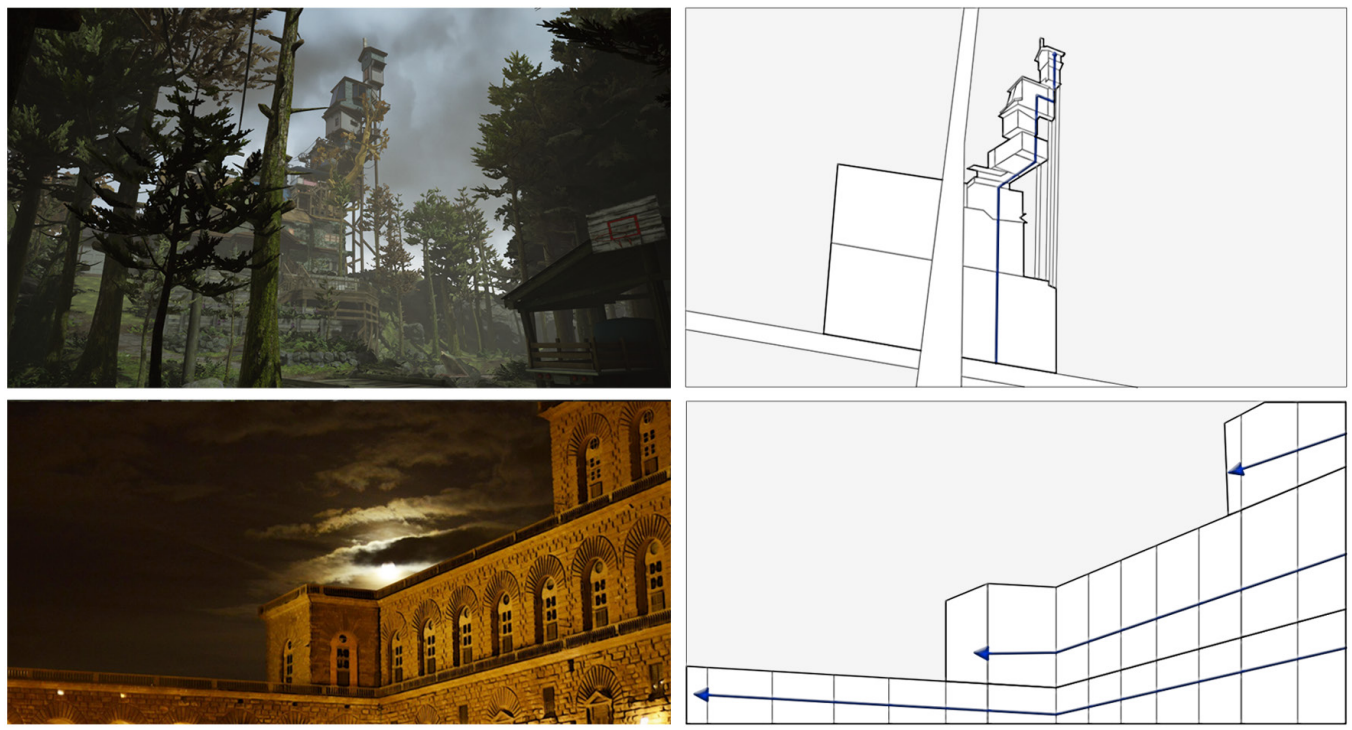


\section{La rappresentazione dello spazio narrativo nei videogames}

Negli ultimi anni, le ricerche sui videogiochi hanno dedicato grande attenzione alla spazialità, unica categoria accettata in maniera concorde come questione centrale nei game studies [Günzel 2008]. Se l'inventario di elementi tematici, quali obiettivi, generi, trame, è pressoché rimasto invariato, è l'insieme di ambientazioni, effetti visivi e interfacce visuali ad essere l'elemento in continuo cambiamento: l'innovazione nei videogiochi, cioè, sta avendo luogo nella loro rappresentazione spaziale; questa, nonostante abbia in comune con gli altri media visuali lo scopo di ospitare azioni narrative [Carson 2000], presenta due fattori contraddistintivi:
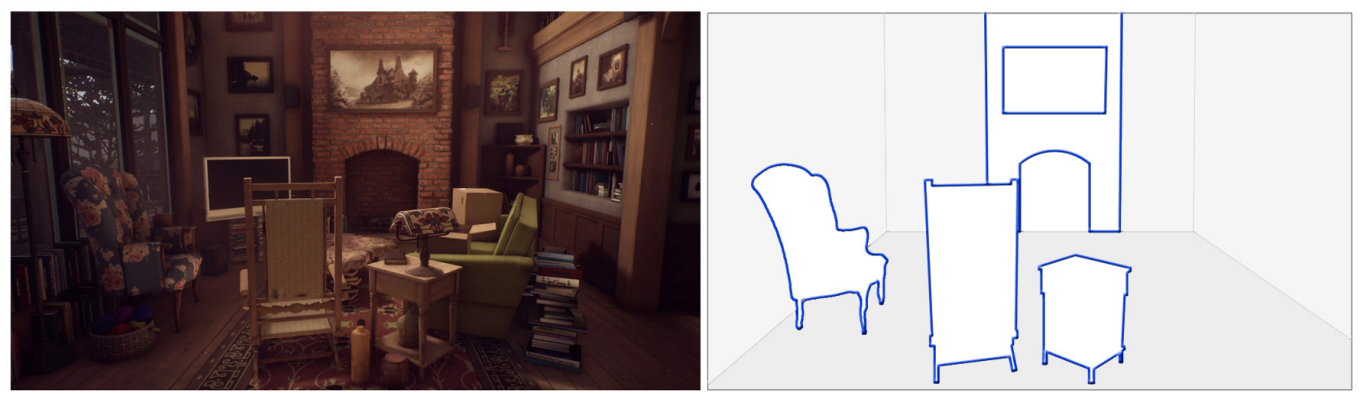

Fig. 2. Confronto tra punto di vista egocentrico (WREF) e punto di vista sensibile al contesto (TMG).
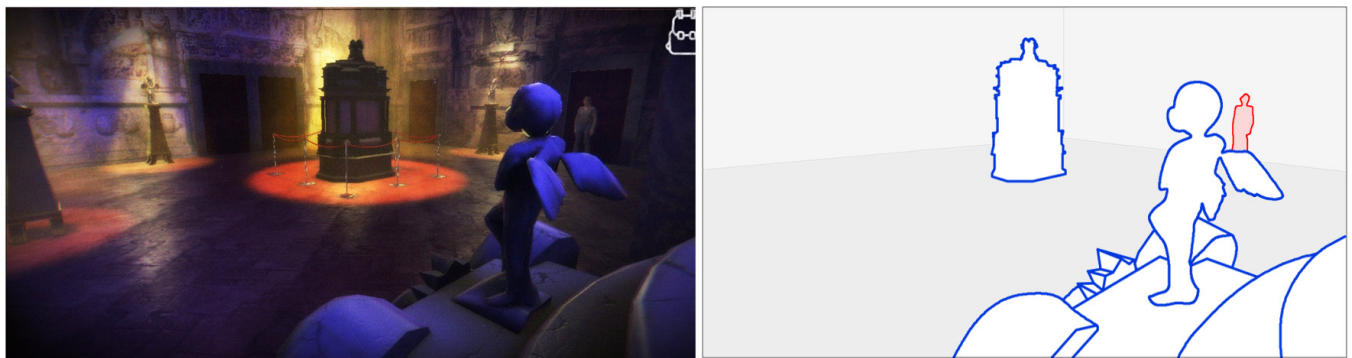

- L'interazione. Se nei media tradizionali il ruolo narrativo dello spettatore è osservare cause ed effetti di azioni non proprie, nel videogioco l'interazione rompe questo meccanismo, ponendo il giocatore al centro della storia: senza di lui la narrazione non potrebbe svolgersi, poiché "i giochi sono azioni" [Galloway 2006, p. 2].

- La navigazione. Nelle immagini tradizionali lo spettatore osserva attraverso una cornice lo "spazio-immagine" [Heath 1986], caratterizzato da specifici elementi spaziali e tecniche rappresentative; nei videogiochi, il giocatore non solo osserva lo spazio, ma può muoversi in esso. II movimento nello spazio, a differenza del cinema, non è ricevuto passivamente, ma è indotto dal giocatore: lo spazio non è più oggetto da guardare, ma luogo da esplorare; il passaggio dal movimento alla navigazione trasforma lo 'spazio-immagine' in un nuovo "immaginario spaziale"' [Günzel 2008].

Per questi motivi, molti videogiochi utilizzano la rappresentazione, capace di 'non rendere il visibile' quanto piuttosto 'rendere visibile' [Florio 2012], per implementare la narrazione. Secondo Jenkins, infatti, i designers di giochi non raccontano storie, ma progettano mondi e scolpiscono spazi necessari a raccontarle; non potendo prevedere ogni azione del giocatore, possono "in qualche modo controllare il processo narrativo distribuendo le informazioni attraverso lo spazio di gioco" [Jenkins 2004]: traducendo precisi significati spaziali in elementi narrativi, essi inducono il giocatore a sviluppare la narrazione. Inoltre, "nonostante la sua mancanza di fisicità, il cyberspazio è un luogo reale" [Wertheim 1999, p. 229]: i gamers, infatti, condizionati dall'esperienza nello spazio reale, abitano lo spazio di gioco riportandovi la propria storia corporea e, di conseguenza, riflettendo la controparte reale anche nella navigazione dello spazio [Flynn 2004]. I designers, pertanto, usano i codici rappresentativi per riproporre nel gamespace quelle relazioni e percezioni che alcuni elementi spaziali stimolano nella realtà fisica. 


\section{La rappresentazione di elementi narrativi. Due videogames a confronto}

La metodologia, volta a definire quali elementi della rappresentazione possano attivare la narrazione nello spazio di gioco, attua il confronto tra un videogame esperienziale e uno culturale; la scelta ricade rispettivamente su What Remains of Edith Finch [WREF], walking simulator vincitore per la miglior narrativa ai Game Awards 2017, e su

[TMG], game culturale realizzato per le Gallerie degli Uffizi di Firenze da Sillabe in coproduzione con Opera Laboratori Fiorentini e con l'associazione TuoMuseo. In WREF la giovane Edith Finch torna nell'ormai abbandonata casa di famiglia per indagare sui suoi familiari, tutti vittime di morti sventurate; in TMG la storica d'arte Caterina, esplorando Palazzo Pitti alla ricerca di un misterioso tesoro, assiste ad un omicidio che la porterà a conoscere i segreti della storica famiglia De Medici. Pur avendo fini diversi, entrambi i giochi sono sfide esplorative in cui la dimensione fisica costituisce elemento necessario e non cosmetico [Adams 20I4]: sia perché l'unico tipo di interazione è ambientale, sia perché solo navigando lo spazio è possibile ricostruire la narrazione. Lo spazio di gioco, in entrambi rappresentativo, ossia "un costrutto navigabile e abitabile che rappresenta un universo fisico riconoscibile" [McGregor 2009, p. 125], può essere comparato poiché simile per dimensioni (è rappresentato in 3D), per scala (è architettonica, gran parte degli eventi si svolge in ambienti interni) e per confini (sono i limiti architettonici degli edifici).

Fig. 3. L'uso dei contrasti 'stretto-ampio' e 'chiupercezioni spaziali diverse (WREF)
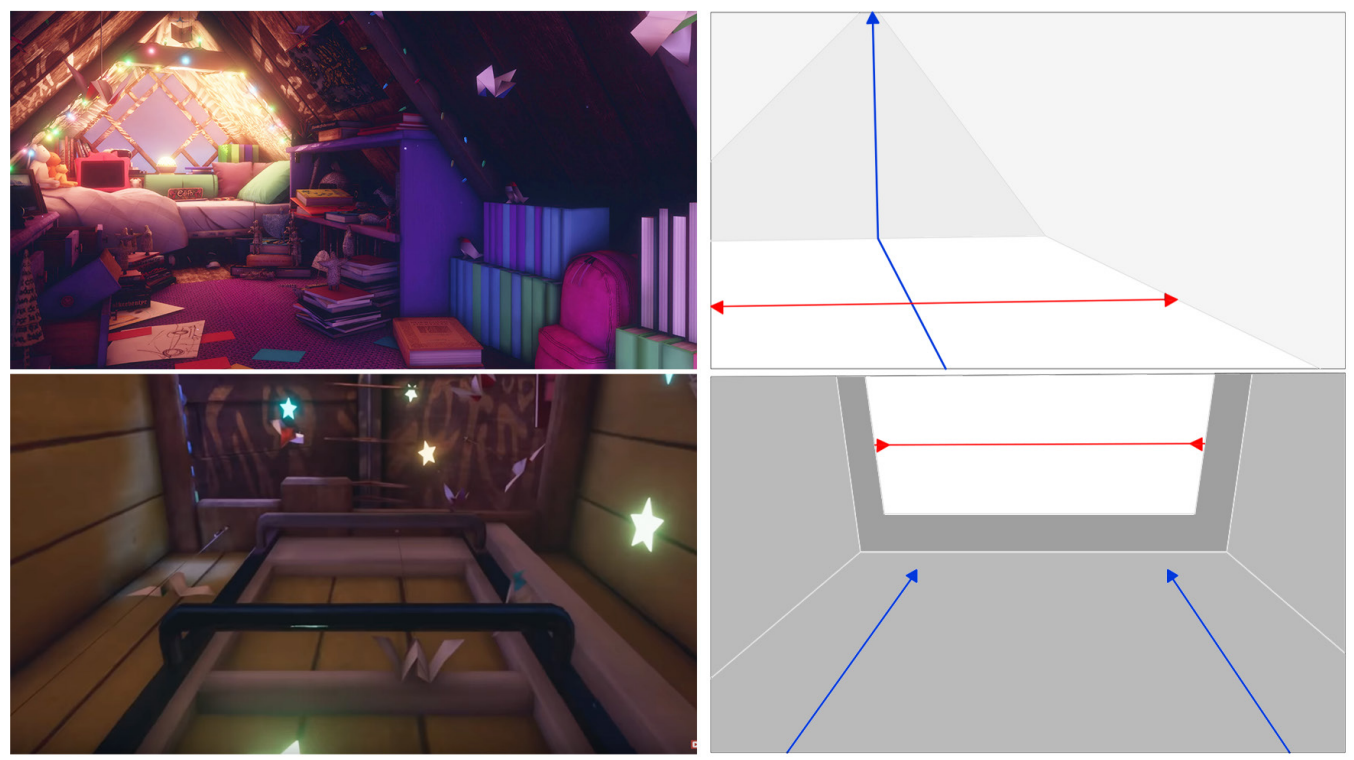

\section{La forma spaziale come landmark narrativo}

La presentazione iniziale dell'architettura può fornire un primo input narrativo. Entrambi i videogiochi si aprono con una vista esterna sugli edifici (fig. I). In WREF il forte senso di verticalità e l'impressionante statura dell'edificio, amplificate dalla vista prospettica dal basso, così come la forma additiva e modulare degli ambienti della casa, gradualmente ridotta verso l'alto, preannunciano lo sviluppo di una narrazione ascendente che troverà conclusione al raggiungimento del modulo abitativo più alto. La forma labirintica della casa, accentuata dai tortuosi percorsi a elica attorno ad essa, informa sulla complessità dell'esplorazione, che tuttavia appare possibile proprio per la fragilità indotta dalla struttura architettonica, precaria e con fondamenta deboli. In TMG la vista iniziale, di scorcio, è dominata da Palazzo Pitti, che occupa gran parte della scena; nonostante la vista angolata, il palazzo non è mostrato nella sua interezza, richiamando, così, ad una complessità narrativa che, a differenza di WREF, si svilupperà principalmente in orizzontale. Nonostante la compattezza dei blocchi costituenti 
ciascun piano e la modularità degli elementi in facciata trasmettano l'idea di una difficoltà esplorativa sia per dimensioni che per capacità di orientamento, le intenzioni narrative non appaiono così evidenti nella prima rappresentazione della forma spaziale.
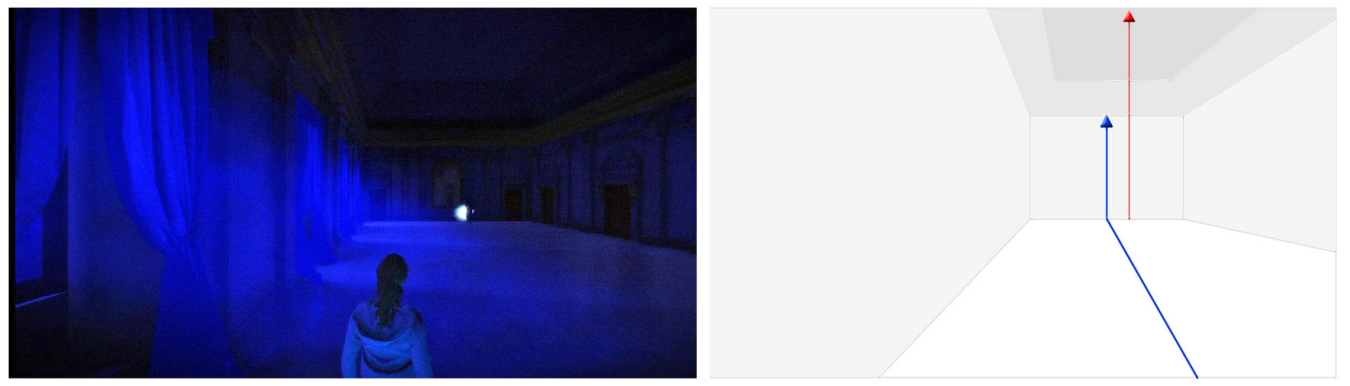

Fig. 4. L'uso dei contrasti 'contratto-dilatato' e
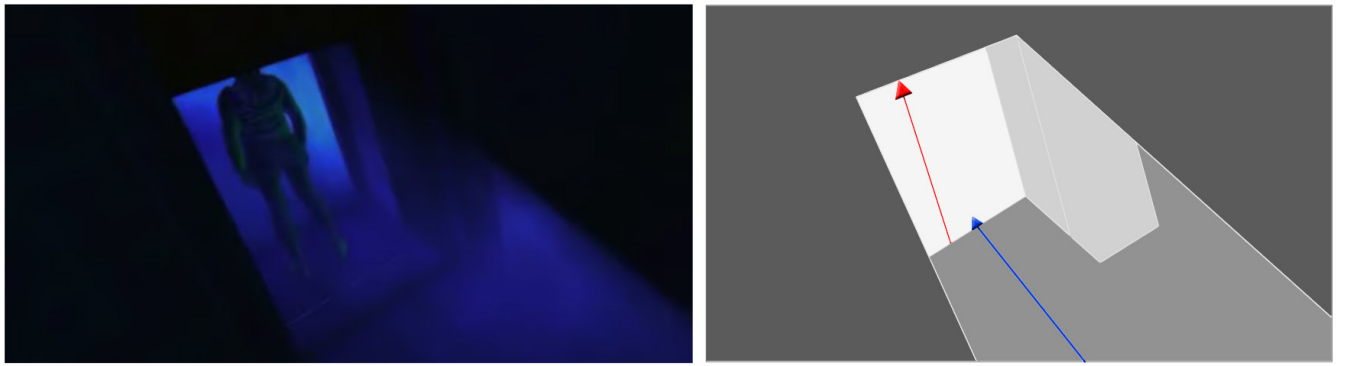

\section{Il punto di vista come suggerimento narrativo}

L'uso di specifici punti di vista può suggerire o orientare la narrazione nel videogioco. In WREF la vista egocentrica del giocatore, sempre in prima persona, genera un sistema di coordinate polari la cui origine è il giocatore stesso e l'asse di riferimento è il suo asse di orientamento [Di Tore, Di Tore, Mangione, Corona 2014. L'assenza di vincoli spaziali rende la navigazione più libera ma anche più complessa; la focalizzazione su specifici elementi è ottenuta bilanciandone i pesi visivi attraverso la gerarchizzazione di scale, colori, trame e forme. Diversamente, in TMG, il punto di vista è sensibile al contesto: l'angolo della camera da ripresa, cioè, si muove nella maniera più consona alla posizione del giocatore nello spazio. Ciò consente l'uso di prospettive scelte e inquadrature specifiche, ideale sia per far conoscere i principali beni storico-culturali e la loro collocazione spaziale, sia per evidenziare gli elementi necessari alla narrazione, come accade nella Sala dei Putti (fig. 2).

\section{L'uso di contrasti per narrare la percezione spaziale}

La riproposizione visiva di qualità duali può definire e accentuare la percezione di uno spazio e il tipo di narrazione proposta in esso [Carson 2000]. In WREF il contrasto è usato come narrazione implicita: la rappresentazione di porte lignee spesse bloccate da sistemi metallici contrapposta a finestre con vetri trasparenti e sottili, fa emergere la possibilità di passaggio dai varchi più fragili. La percezione spaziale è poi ottenuta giustapponendo spazi opposti: così come gli architetti delle cattedrali medievali progettavano l'attraversamento di uno spazio piccolo prima dell'ingresso in chiesa, per dilatarne le dimensioni, così in WREF la soffitta appare ariosa e grande poiché fatta precedere da un cunicolo verticale stretto e chiuso (fig. 3). Anche TMG usa questa contrapposizione per narrare il senso del luogo: prima di entrare nella grande Sala degli Stucchi, il giocatore è contenuto in uno spazio buio e compresso; man mano che entra nella sala, la luce fluisce al suo interno, il soffitto si alza e lo spazio si apre, evocando un'esperienza molto più regale e grandiosa che se l'intero spazio fosse stato ampio e illuminato dall'inizio (fig. 4). 


\section{I giochi di luce per condurre la narrazione}

Abbiamo visto come l'uso di contrasti possa contribuire a generare particolari atmosfere e percezioni spaziali; in particolar modo nei videogiochi esplorativi è la dualità luce/ombra a determinare l'aria di mistero. Questo contrasto, inoltre, può aiutare lo sviluppo della narrazione. In WREF permette infatti di indirizzare i movimenti del giocatore nello spazio, facendogli esplorare alcuni spazi prima di altri (fig. 5). In TMG la luce, invece, permette di focalizzare l'attenzione su quegli elementi spaziali che hanno un valore narrativo e non fungono solo da contesto. Nel videogame culturale, tuttavia, non tutte le sale sono illuminate secondo una logica narrativa: mentre nella Sala Verde il bilanciamento di zone in luce e in ombra aiuta ad orientare le azioni del giocatore, dando peso visivo maggiore agli elementi architettonici e a i beni culturali rivelatori di sequenze narrative, nella Sala del Trono l'ambiente illuminato in maniera uniforme rende più chiara l'immagine dello spazio ma più complessa la narrazione e le scelte del giocatore (fig. 6).
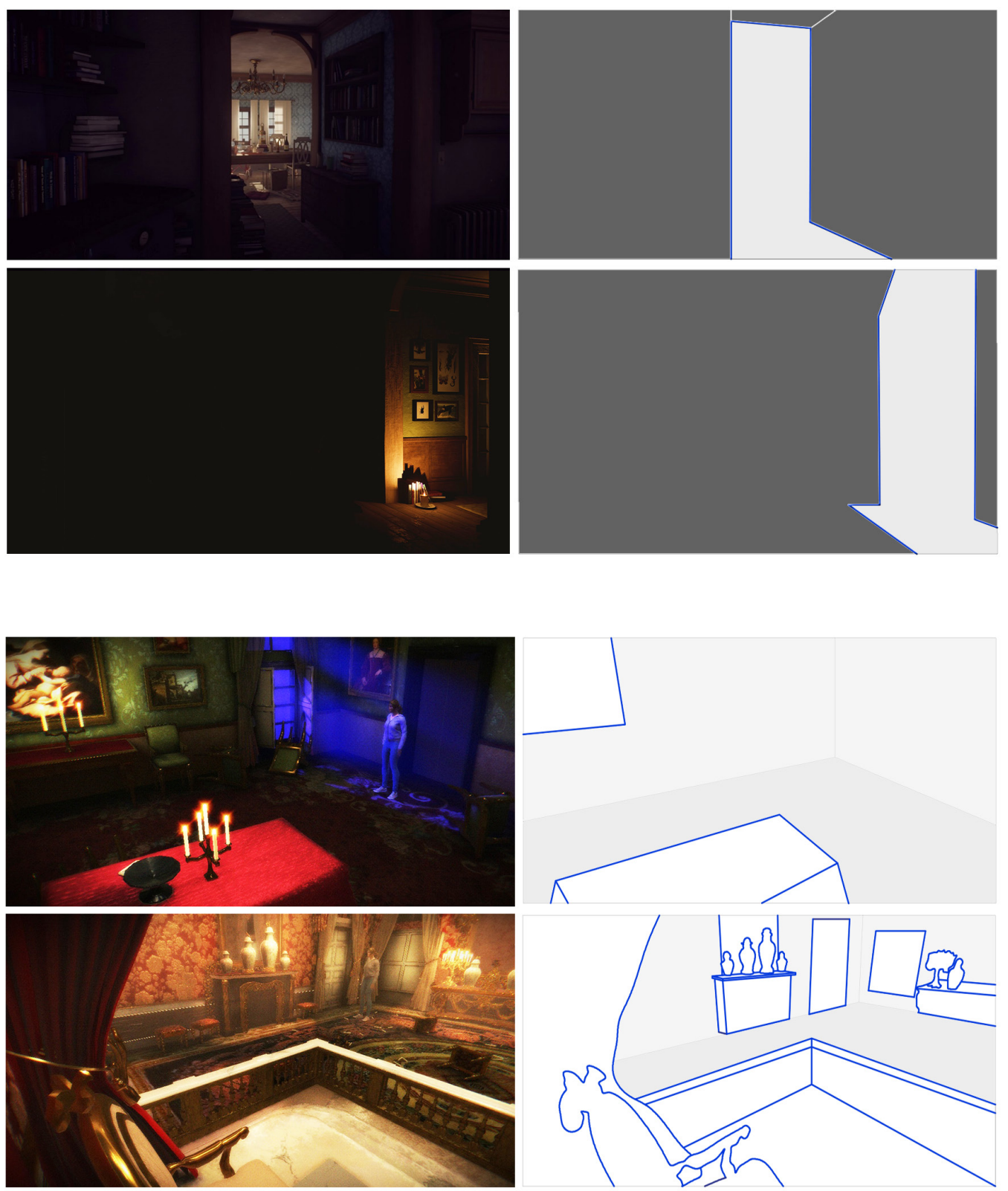


\section{I dettagli architettonici come indizi narrativi}

I dettagli architettonici possono fornire indicazioni narrative; se rappresentati solo in specifiche aree, diventano delle frecce direzionali atte a guidare il giocatore nelle zone in cui si desidera attirare la sua attenzione. In WREF la presenza di dettagli narra la funzione degli spazi: la rappresentazione della dispensa (fig. 7), scarna e priva di decorazioni, con un particolare elemento di richiamo posto nella profondità dell'ambiente, è un espediente per descrivere uno spazio che deve essere attraversato ma non esplorato. L'inserimento di dettagli avrebbe sì reso più realistico l'ambiente, ma avrebbe fatto perdere la narrazione in uno spazio che ha solo funzione di connessione. Le camere da letto, invece, presentano innumerevoli dettagli (fig. 8): sono spazi da esplorare con attenzione e, quindi, contenitori di indizi narrativi. In TMG, nonostante la difficoltà maggiore di ricreare un modello digitale fedele alla realtà delle sale e delle opere d'arte di Palazzo Pitti, il processo interpretativo di riduzione dei dettagli e l'equilibrio della loro distribuzione nella rappresentazione, li rendono coprotagonisti della narrazione: i fregi attorno allo specchio centrale, ad esempio, unico elemento di dettaglio nella Sala Bianca, nascondono uno scomparto misterioso (fig. 9), così come il dettaglio di una linea di contorno rettangolare su una parete della Sala del Gabinetto Ovale indica la presenza di un passaggio segreto (fig. I0).

Fig. 7. La riduzione di dettagli per narrare la funzione connettiva della dispensa (WREF).
Fig. 8. L'aggiunta di dettagli per narrare la funzione esplorativa delle cam da letto (WREF).
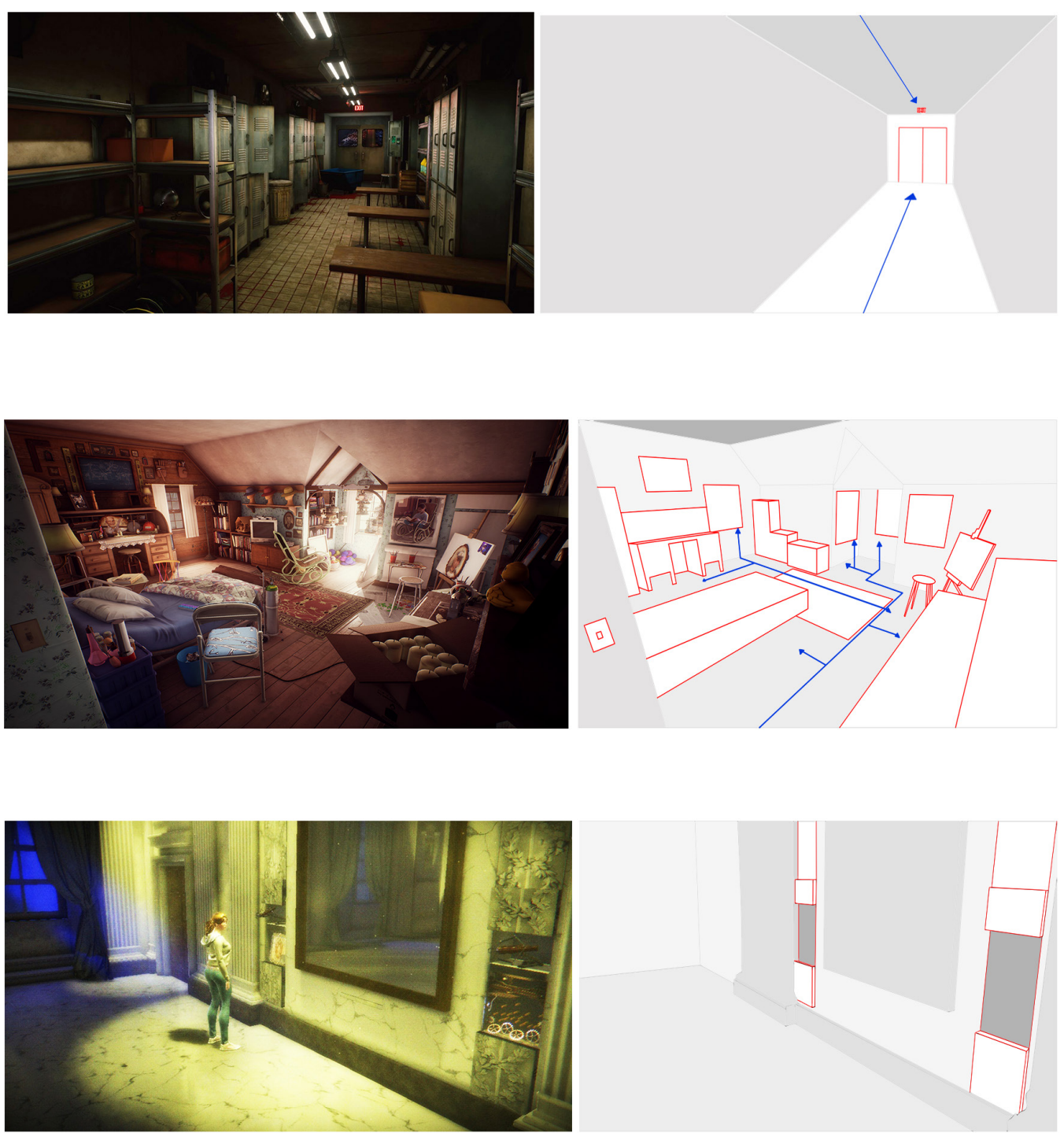
Fig. 10. II dettaglio della linea di contorno sulla parete della Sala del Gabinetto Ovale come indizio narrativo (TMG)

\section{Conclusioni}

La ricerca indaga il ruolo che la rappresentazione può assumere nella narrazione del patrimonio attraverso il videogame culturale. II confronto con un videogame esperienziale evidenzia le potenzialità narrative che la rappresentazione spaziale può incentivare nel passaggio da storytelling a story-doing [Viola 20 17]: solo esplorando lo spazio e interagendo con i suoi elementi, infatti, il giocatore può costruirne il racconto sotteso, divenendone protagonista. La rappresentazione, se proposta nel suo ruolo scientifico di traslitterazione segnica di processi conoscitivi, interpretativi, sintetici e ri-presentativi, può costituire, dunque, una strategia per connettere videogame e museo; stimolando la conoscenza del patrimonio culturale attraverso nuovi linguaggi aperti, il videogame può rispondere al ruolo odierno del museo, ossia di "essere il luogo della scoperta; fornire degli stimoli all'appetito scientifico, senza pretendere di essere esaustivi; [...] offrire occasioni e spazi di cui il visitatore fruirà liberamente, vivendo delle esperienze il cui impatto maggiore sarà sugli atteggiamenti e le sensibilità" [Merzagora, Rodari 2007, p. 9].
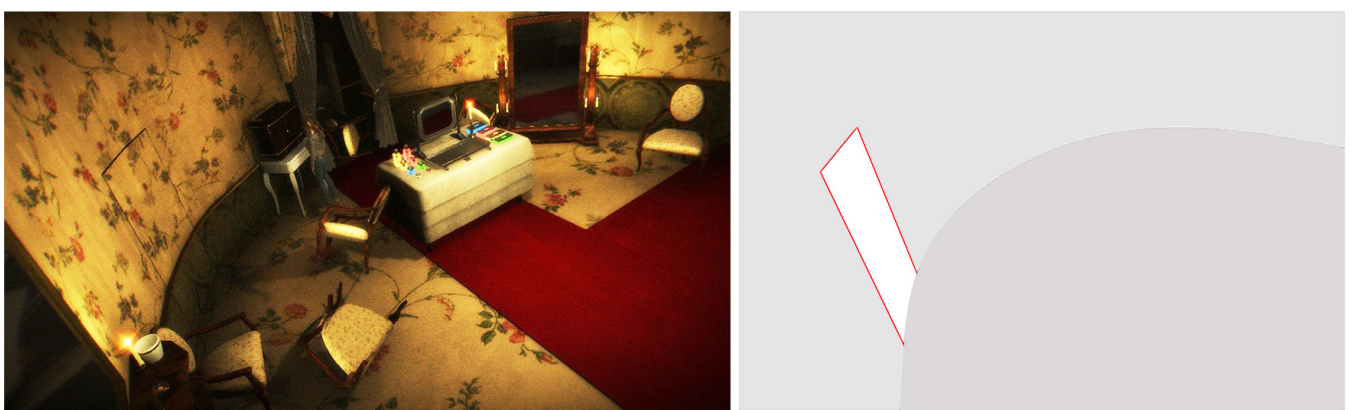

\section{Riferimenti bibliografici}

Adams Ernest (2014). Fundamentals of Game Design. San Francisco: New Riders.

Beale Katy (20I I). Museum At Play: Games, Interaction and Learning. London: MuseumEtc

Bergamo Francesco, Bortot Alessio, Boscaro Cristian et al. (2016). Un percorso fruitivo e conoscitivo degli apparati pittorici del Convento della SS. Trinità dei Monti a Roma. In Disegnarecon, vol. 9, n. I7, pp. 2. I -2.9

Carson Don (2000). Environmental Storytelling: Creating Immersive 3D Worlds Using Lessons Learned From the Theme Park Industry. In Gamasutra, online journal, march 2000, pp. I-4.

Chaplin Heather, Zimmerman Eric (20I3). Manifesto: The 2 I st Century will be defined by Games. In Kotaku, online journal, september 2013

Di Tore Pio Alfredo, Di Tore Stefano, Mangione Giuseppina Rita, Corona Felice (2014). Spazio, movimento, prospettiva ed empatia: un prototipo di videogame didattico. In Form@re, Open Journal per la formazione in rete, n. 3, vol. I 4, pp. 43-6I.

Flynn Bernadette (2004). Games as Inhabited Spaces. In The Games Issue, n. I I 0, pp. 52-6I.

Florio Riccardo (2012). Sul disegno. Riflessioni sul disegno di architettura. Roma: Officina.

Galloway Alexander (2006). Gaming. Essays on Algorithmic Culture. Minneapolis: University of Minnesota Press.

Günzel Stephan (2008). The Space-Image. Interactivity and Spatiality of Computer Games. In Günzel Stephan, Liebe Michael, Dieter Mersch (eds.). Philosophy of Computer Games. Potsdam: University Press, pp. 170- 189.

Heath Stephen (1986). Narrative Space. In Rosen Philip. Narrative,Apparatus, Ideology. A Film Theory Reader. New York: Columbia University Press, pp. 379-420.

Higuinen Erwan, Tesson Charles (2002). Éditorial. Chinèphiles et Ludophiles. In Cahiers du Cinèma, n. spec. sett. 2002 , p. 5.

Jenkins Henry (2004). Game Design as Narrative Architecture. In Wardrip-Fruin Noah, Harrigan Pat. First Person: New Media as Story, Performance and Game. Cambridge MA:The MIT Press, pp. I I 8- I 30.

Maldonado Tomas (20I5). Reale e Virtuale. Milano: Feltrinelli Editore.

Manovich Lev (2005). Il linguaggio dei nuovi media. Milano: Edizioni Olivares. Collana Nuovi Media. 
McGregor Georgia Leigh (2009). Gamespace. Play \& Architecture in Videogames. Doctoral Thesis of Philosophy. School of Media Arts, University of New South Wales.

Merzagora Matteo, Rodari Paola (2007). La scienza in mostra. I musei scientifici e il pubblico. Milano: Bruno Mondadori.

Murray Janet H. (2006). Toward a cultural theory of gaming. In Popular Communication, n.4, pp. I 85-202.

Prensky Marc (20।3). La mente aumentata. Dai nativi digitali alla saggezza digitale (Trad. di R. Sardi). Trento: Erickson.

Salvarani Renata (2005). Storia locale e valorizzazione del territorio. Dalla ricerca ai progetti. Milano:Vita e pensiero.

Toscano Mario, Gremigni Elena (2008). Introduzione alla sociologia dei beni culturali. Testi Antologici. Firenze: LeLettere.

Viola Fabio (20 17). L'arte del coinvolgimento. Emozioni e stimoli per cambiare il mondo. Firenze: Hoepli.

Wertheim Margaret (1999). The pearly gates of cyberspace:A history of space from Dante to the Internet. Sydney: Doubleday.

\section{Autore}

Greta Attademo, Università degli Studi di Napoli “Federico II”, greta.attademo@unina.it

Per citare questo capitolo: Attademo Greta (2020).Videogame e museo. La rappresentazione dello spazio come strumento narrativo per il patrimonio culturale/Videogame and museum. The spatial representation as a narrative strategy for the cultural heritage. Arena A., Arena M., Brandolino R.G., Colistra D., Ginex G., Mediati D., Nucifora S., Raffa P. (a cura di). Connettere. Un disegno per annodare e tessere. Atti del $42^{\circ}$ Convegno Internazionale dei Docenti delle Discipline della Rappresentazione/Connecting. Drawing for weaving relationships. Proceedings of the 42 th International Conference of Representation Disciplines Teachers. Milano: FrancoAngeli, pp. 2955-2972. 


\title{
Videogame and Museum. The Spatial Representation as a Narrative Strategy for the Cultural Heritage
}

\author{
Greta Attademo
}

\section{Abstract}

The gamification of communication and the advent of New media, of which the video game is the emblem, have caused, in our century, a paradigm shift in the man's ways of knowing and being in the world, inviting reflection on the role of the representation in the rethinking of the relationship among society, images and narration. The representation in fact, having always been a universal communication code due to its ability to translate complex meanings into a visual system of signs, is also used today by museums as a narrative language able to make its cultural heritage more usable. Its use, however, is often limited to the realization of spectacular images, reinvigorated by technologies, rather than oriented to its communication skills. This research, therefore, investigates the representation as a possible narrative strategy in video game. By analyzing new medium's distinctive factors, the central role of the representation of the space emerges as a tool to implement the narration underlying the game. The comparison between the experiential video game What Remains of Edith Finch and the cultural video game The Medici Game. Murder at Pitti Palace reveals elements and ways through which the spatial image can take action on the narration, stimulating the knowledge of the cultural heritage and so creating a connection between the video game's open languages and the current role of the museum intended as an informal learning environment.

Keywords

cultural videogame, museum, narrative space, gamification, cultural heritage.

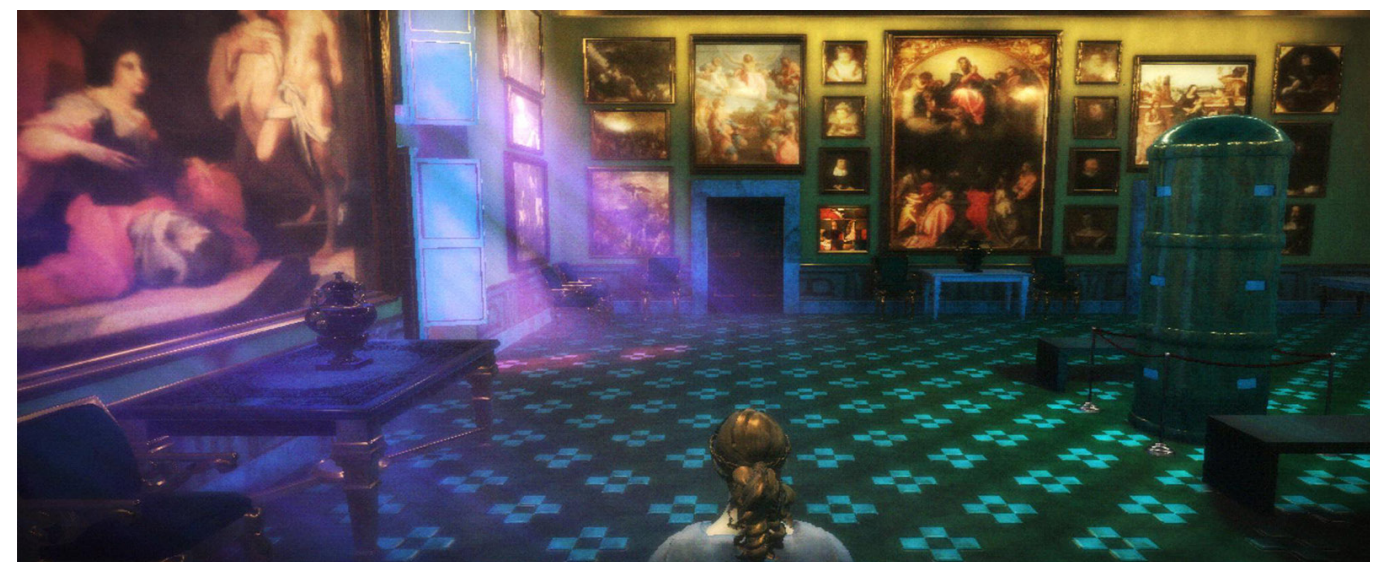




\section{Introduction}

The games' pervasive role in our time has led scholars to talk not only about a 'ludic century' [Chaplin, Zimmerman 20 I3] but also about a 'ludic turn' [Murray 2006], that has systematically changed the structure of the information into more playable and creative approaches, thanks to the advent of new media, leading to a paradigm shift in the man's ways of knowing and being in the world.Video games, in fact, emblem of our time, "are not only a social phenomena, they are the essential crossroads of a redefinition of our relation to the narrative world in images" [Higuinen, Tesson 2002, p. 5]; in fact, their ability to create new narrative modalities, other than those of other media, makes them carriers of new meanings for the representation. This last one has been an important means of communication between experts and collectivity over the centuries, when it was revealing not a generic reality but the perception of the reality in which it was establishing [Maldonado 20 I5]; in other words, when its role as a tool of transcription of the visible reality - already contained in the same root 'idein/to see' of the words 'eidos/idea' and 'eidolon/image' - mediated between sensory-seeing and intelligible-seeing. It is not coincidence that the representation is also used today by museums as a narrative language able to make its cultural heritage more usable, taking into consideration that in today's society the concept of information culture is a parallel to that of the visual culture [Manovich 2005, p. 39] and that the cultural audience, comprising both 'digital immigrants' and 'digital natives' [Prensky 20।3] need different ways of communication in order to understand those innate meanings in Cultural Heritage that otherwise would risk "of remaining mute without subjects able to perceive and interpret them" [Toscano, Gremigni 2008, p. I45]. Some cultural institutions, however, have limited the potentialities of the representation into sensationalize the images, rather than highlight its interpretive skills; the digital component was understood as an exclusive guarantor of a correct communication, without considering that "the invisible information which any artefact conveys per se, beyond the mere material dimension" [Bergamo, Bortot, Boscaro et al. 2016, p. 3] it makes sense only if it is transmitted through a cultural action in which the community can recognize themselves [Salvarani 2005]. Starting from the idea of the static image as the symbol of the typical passive contemplation of the last-century museum, the research sets out to investigate the video game, in its double dimension as a image and action, as a possible reading key of the contemporary museum, understood as a "holder of stories rather than artworks or exhibits" [Beale $201 \mathrm{ll}$.
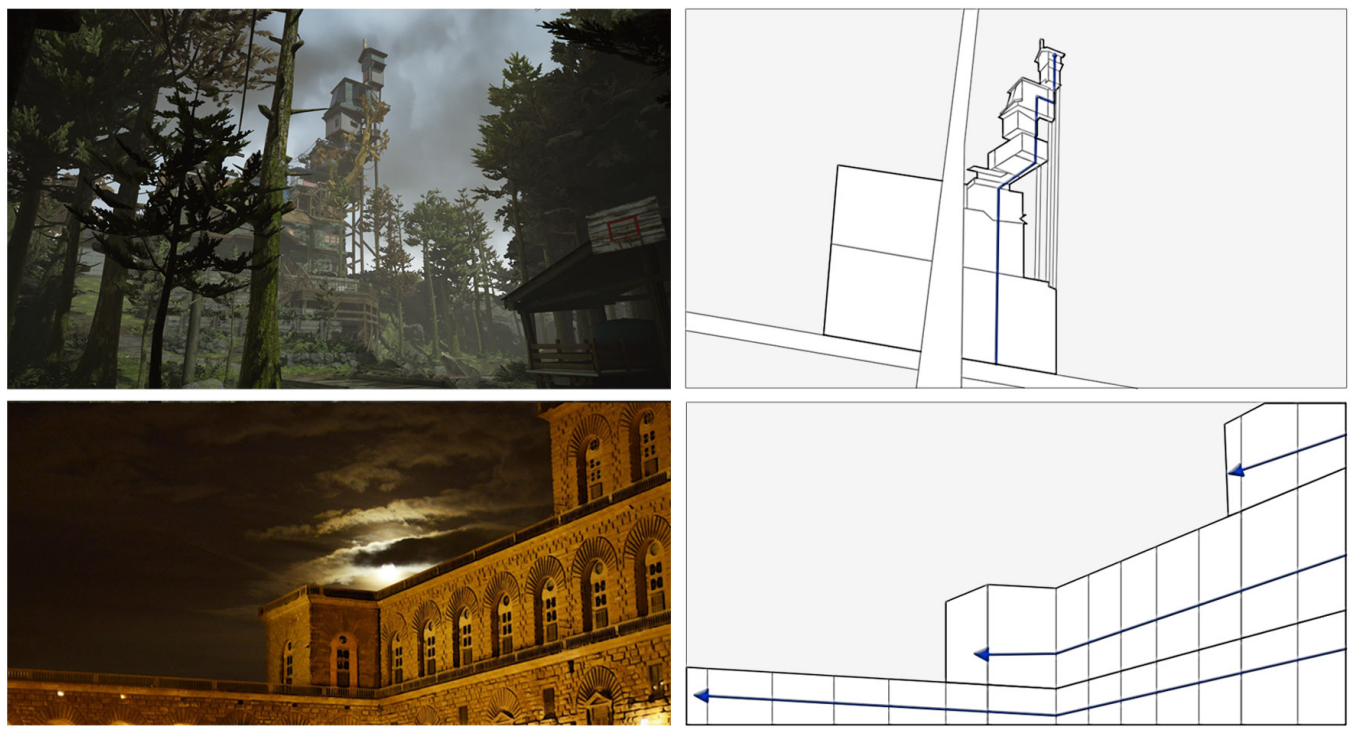


\section{The representation of narrative space in video games}

Within the last few years, research on video games have paid much attention to the spatiality, the one category that has come to be accepted as the central issue of game studies [Günzel 2008]. If the inventory of thematic and structural elements, such as goals, genres and plots, don't have changed much, what is constantly changing is the set of environments, visual effects and visual interfaces: the video game innovation, that is, takes place in their representation of the space; this one, although has common with other visual media the scope to accommodate narrative actions in [Carson 2000], has two distinctive factors:
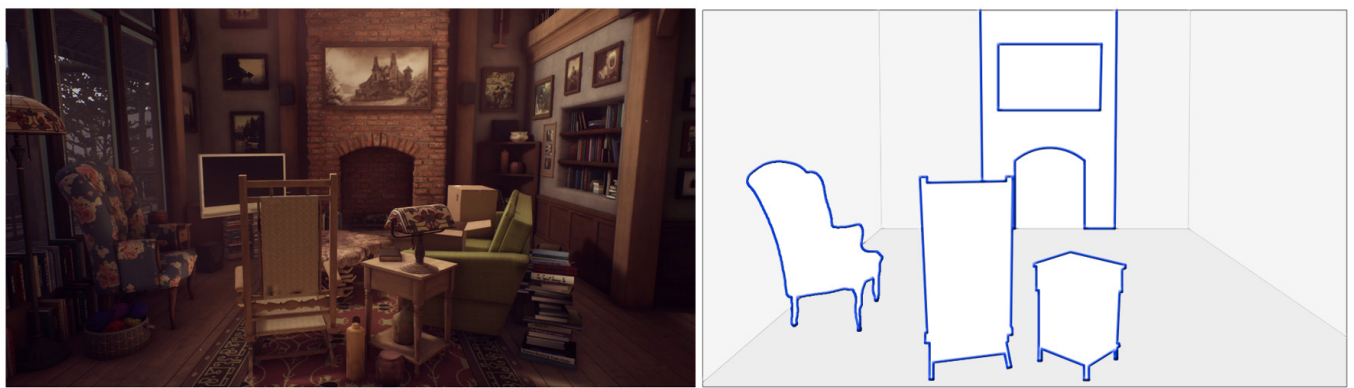

Fig. 2. Comparison between egocentric point of view (WREF) and point of view susceptible to the context (TMG).
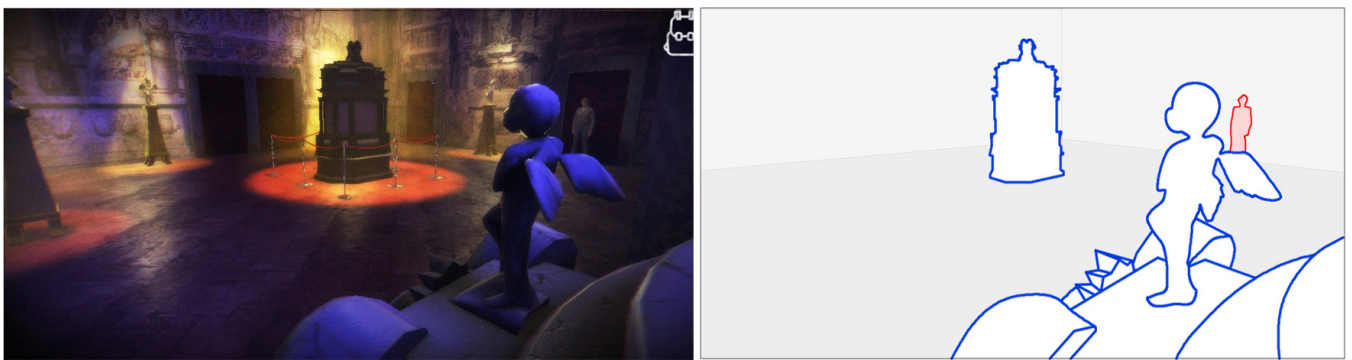

- The interaction. If the narrative role of the spectator in traditional media is to observe causes and effects related to not own actions, the interaction breaks this mechanism in the video game, placing the player at the centre of the story: the narration could not take place without him, because "games are actions" [Galloway 2006, p. 2].

- The navigation. In the traditional images, the spectator observes, through a frame, the "image-space", characterized by specific spatial elements and depiction techniques [Heath 1986]; in video games, the player not only observes the space, but he can also moves into it. The movement in space is not received passively as in cinema, but it is induced by the player: the space is no longer an object to observe, but it is a place to explore; the transition from the movement to the navigation transforms the 'image-space' into a new "space-image" [Günzel 2008].

Many video games, for these reasons, use the representation, able to 'not make what one sees' but rather 'to make visible' [Florio 2012] in order to implement the narration. According to Jenkins, in fact, game designers tell no tales, but they design worlds and sculpt spaces that are necessary to tell them; they, being unable to predict every player's action, can "somewhat control the narrational process by distributing the information across the game space" [Jenkins 2004, p. 9]: transforming precise spatial meanings into narrative elements, they persuade the player into developing the narration. In addition, (despite its immaterial nature, the cyber-space is a real place) [Wertheim 1999, p. 229]: gamers, in fact, conditioned by the experience in the real space, inhabit the game space bringing in it their corporeal history and, consequently, mirroring the real-life counterpart also in the space navigation [Flynn 2004]. Designers, therefore, use representative codes in order to repropose, inside the game space, those relationships and perceptions that some spatial elements stimulate in the physical reality. 


\section{The representation of narrative elements. A comparison between two video games}

The methodology operates a comparison between an experiential video game and a cultural video game, in order to define which elements of the representation can activate the narration in the game space; the choice falls, respectively, on What Remains of Edith Finch [WREF], a walking simulator, winner for the best narrative in the Game Awards 20 17, and on The Medici Game. Murder at Pitti Palace [TMG], a cultural game realized for Uffizi Museum in Florence by Sillabe in co-production with Opera Laboratori Fiorentini and with TuoMuseo association. In WREF the young Edith Finch returns to the now abandoned family home to investigate her family members, all victims of hapless deaths; in TMG the art historian Caterina, exploring Pitti Palace in search of a mysterious treasure, assists in a murder that will lead her to discover the secrets of the Medici historical family. Despite employed for different purposes, both games are explorative challenges in which the physical dimension is a necessary and non-cosmetic element [Adams 2014]: this is because the only type of interaction is environmental and also because, only through the navigation of the space, it is possible to piece together the narrative. In both games the space is representative, namely "a navigable and inhabitable construct that represents a recognizable physical universe" [McGregor 2009, p. 125], and it can be compared because it similar in dimensions (it is represented), scale (it is architectural, most events take place in the interior) and boundaries (they are the buildings architectural limits).

Fig. 3. The use of the contrasts 'narrow-wide' and 'enclosed-airy' to narrate different spatia perceptions (WREF)
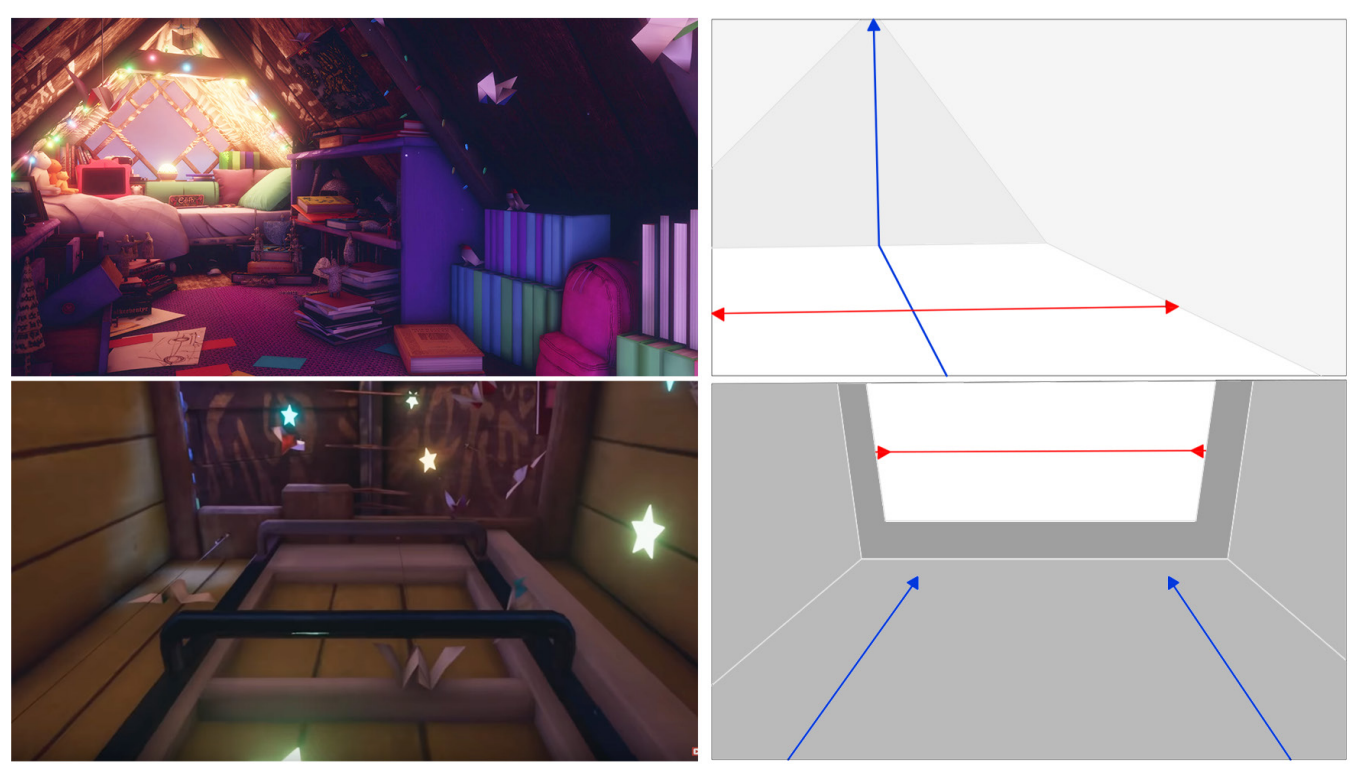

The spatial form as a narrative landmark

The initial presentation of the architecture can provide a narrative input. Both video games start with an external view of the buildings (fig. I). in WREF the strong sense of verticality and the impressive stature of the building, amplified by the perspective view from below, as well as the additive and modular shape of the rooms of the house, gradually reduced upwards, announce the subsequent development of an ascending narration that would probably find its conclusion in the reaching of its highest living module. The maze-shape of the house, accentuated by the twisting spiral pathways around it, provides information about the complexity of the exploration, that nevertheless appears possible due to the fragility induced by the architectural structure, that is precarious and it has weak foundations. In TMG the initial panoramic view is dominated by Pitti Palace, that occupies the scene largely; despite the view is angled, it does not show the whole building, thus recalling a narrative complexity that, in contrast to WREF, will develop horizontally. Even if the compactness of 
blocks which constitute each floor and the modularity of façade elements suggest a difficult exploration both for its size and for the ability of orientation, the narrative intentions are not so clear in the first representation of the spatial form.
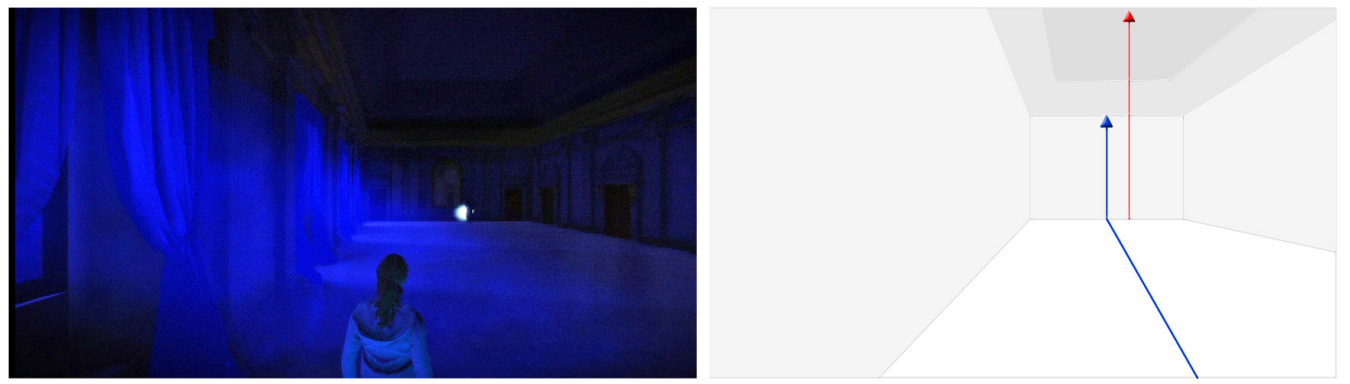

Fig. 4. The use of the contrasts 'compresseddilated' and 'darkilluminated' to narrate different spatial perceptions (TMG)
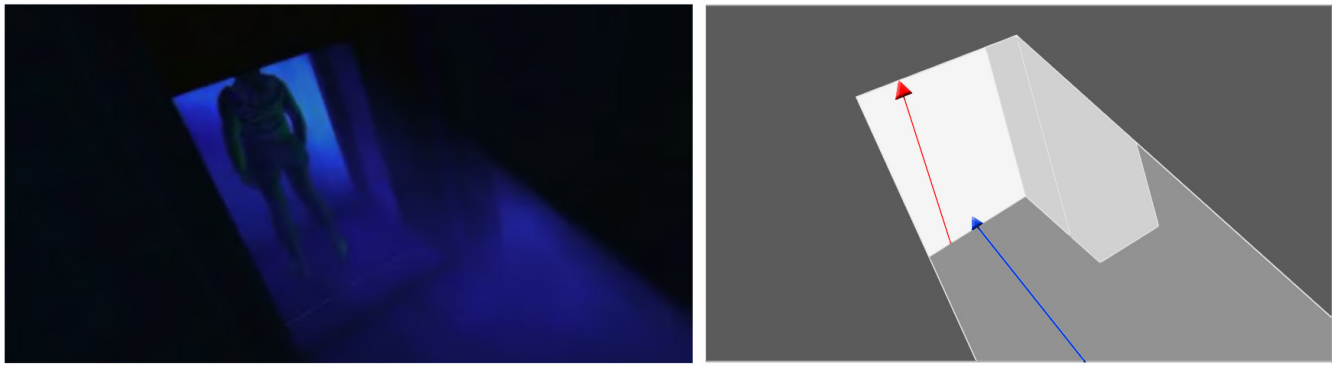

\section{The point of view as a narrative suggestion}

The use of specific points of view can suggest or guide the narration in video game. In WREF the egocentric player's view, always in first person, generates a polar coordinate system where the center is the player itself and the reference axis is its orientation axis [DiTore, Di Tore, Mangione, Corona 20 I 4]. The absence of spatial limits make the navigating experience freer but also more complex; the focalization on specific elements is obtained balancing their visual weights through the hierarchisation of scales, colors, textures and shapes. InTMG, differently, the point of view is susceptible to the context: the angle view of the camera, moves in a more consonant manner with the player position in the space. This allows the use of chosen perspectives and specific camera angles, ideal both for promoting the knowledge of main historical and cultural goods and their spatial position, and for highlighting the elements necessary for the narration, as happens in Sala dei Putti (fig. 2).

\section{The use of contrasts to narrate the spatial perception}

The visual reproposal of dual features can define and accentuate the perception of a space and the type of narration present in it [Carson2000]. In WREF the contrast is used as an implicit narration: the representation of thick wooden doors with metallic locking system as opposed to transparent and thin glass windows, reveals the possibility to move through the more fragile passages. The spatial perception is then obtained juxtaposing opposite spaces: as well as the architects of medieval cathedrals designed the crossing of a little space before the entrance in the church in order to make it seem larger, also in WREF the attic looks airy and big because it is prefixed with a narrow and enclosed vertical tunnel (fig. 3). Also TMG use this contraposition to narrate the sense of place: before entering the big 'Sala degli Stucchi', the player is located in a dark and compressed space; light flows through the room, the ceiling lifts off and the space opens, as the player gradually comes into the room; this conjures up a much more regal and greater experience than if the whole space were large and illuminated from the start (fig. 4). 


\section{The plays of light to carry the narration}

We have seen how the use of contrast can contribute to generate particular atmospheres and spatial perceptions; in particular, the duality light/shadow is used in explorative video games in order to create a certain air of mistery. This contrast can also help the development of the narration. In WREF, in fact, it allows to direct the movements of the player in the space, leading him to explore some spaces sooner than others (fig. 5). Instead, in TMG the light allows to focus attention on those spatial elements that have a narrative value and that not only serve as a framework. In the cultural videogame, however, not all rooms are illuminated according to a narrative logic: while the balance of light areas and shadow areas helps the player to orient his actions in the 'Sala Verde', giving a greater visual weight to the architectural elements and to the cultural goods that reveal narrative sequences, the environment in the 'Sala del Trono', that is illuminated evenly, makes the image of the space more clear but also it makes more complex the narration and the player's choices (fig. 6).

Fig. 5. Use of light and shadow in order to guid the narration and the movements of the playe (WREF).
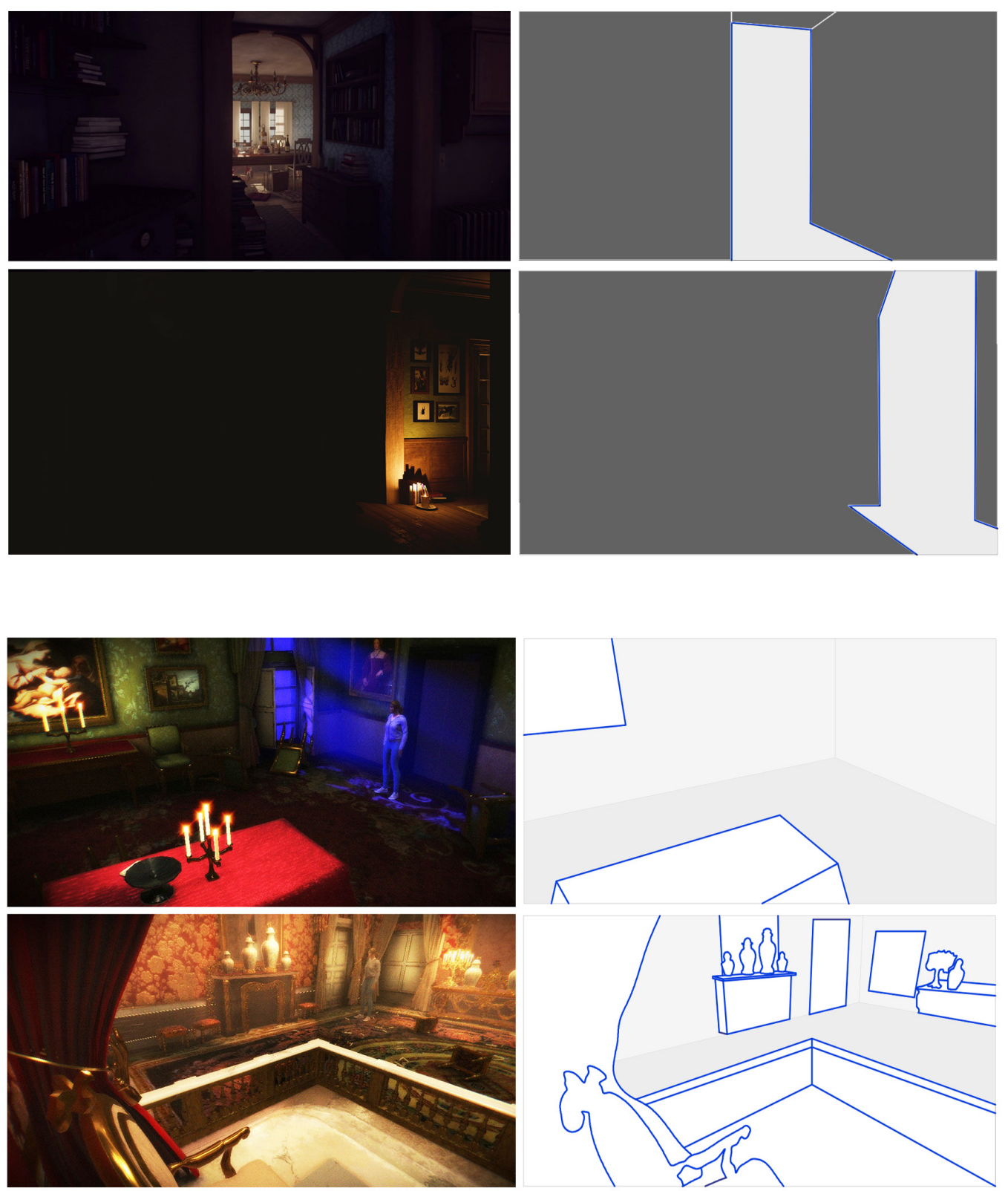


\section{Architectural details as narrative clues}

The architectural details can provide narrative information; If they are represented only in specific areas, they become directional arrows aimed to guide the player in areas where you want attract his attention. In WREF the presence of details narrates the functions of the spaces: the representation of a sparse and undecorated pantry (fig. 7), that presents a particular eye-catcher positioned in the depth of the space, is a ploy to describe a space that must be walked through but that does not need to be explored. Including details would made it certainly more realistic, but it would have lost the narration in a space that only has a connection function. Bedrooms, on the contrary, present innumerable details (fig. 8): they are spaces to be carefully explored and so they contain narrative clues. In TMG, the interpretative process of reducing details and the balance of their distribution in the representation make them co-protagonists, despite the greatest difficulty of recreating a digital model conforming exactly to reality of Pitti Palace's environments and artworks: the friezes around the central mirror, for example, hold a hidden compartment, being the only detailed element in the 'Sala Bianca' (fig. 9); similarly the detail of a rectangular contour line on a wall in the 'Sala del Gabinetto Ovale' indicates the presence of a secret passage (fig. I0).

Fig. 7.The reduction of details in order to narrate the connective function of the pantry (WREF).
Fig. 8. The addition of details in order to narrate the explorative (WREF)
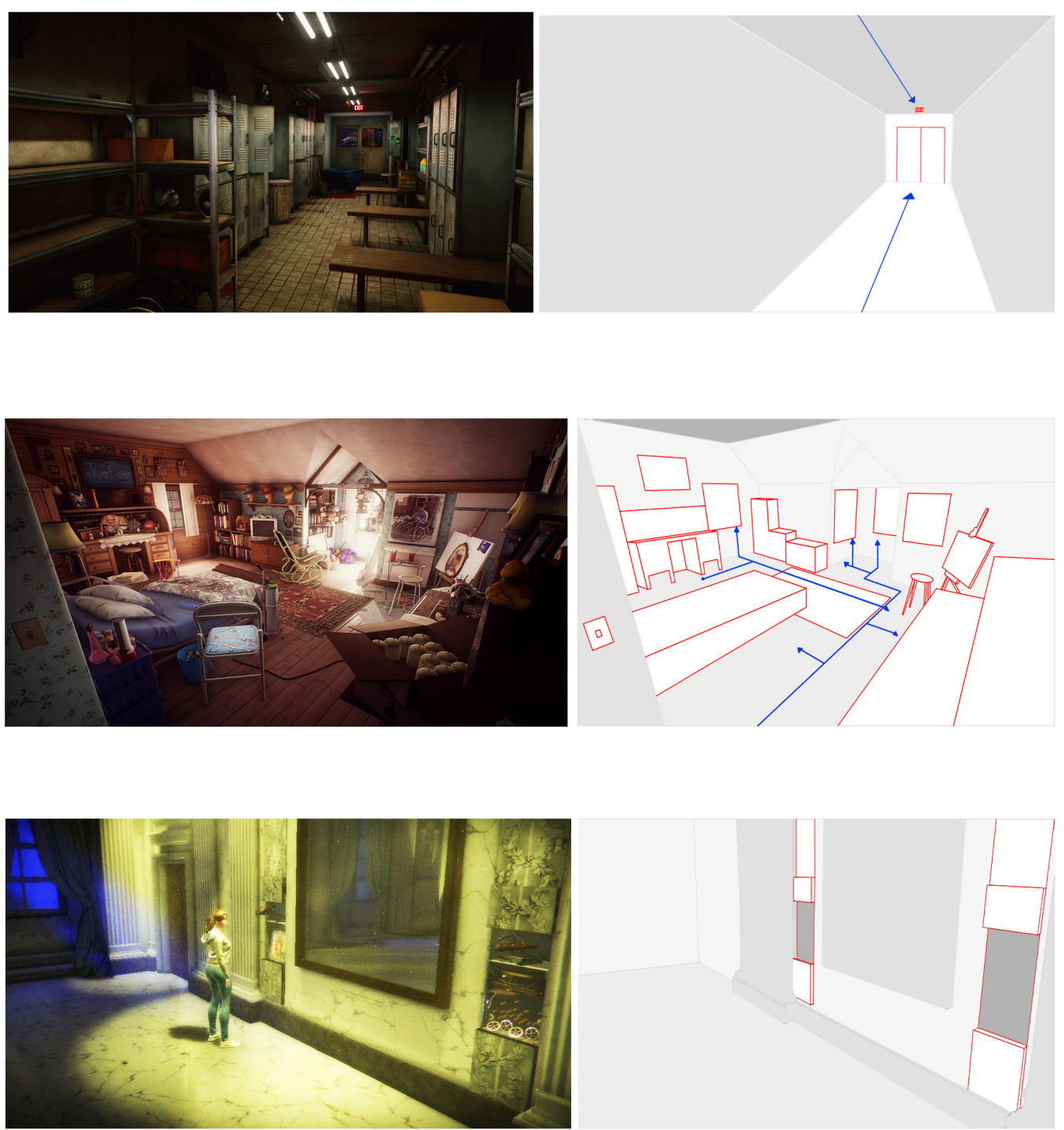


\section{Conclusions}

The research investigates the role which can be played by the representation within a cultural videogame in the narration of the Cultural Heritage. The comparison with an experiential videogame highlights the narrative potentialities that spatial representation may encourage in the transition from storytelling to story-doing [Viola 2017]: the player, in fact, can piece together the narration only exploring the space and interacting with its elements, becoming so the protagonist. The representation can constitute, therefore, a strategy to connect videogame and museum, if presented according to its scientific role of transliteration of cognitive, interpretative, synthetic and re-presentative processes into signs; video game can fit within the role of today's museum, which is "to be the place of discovery; to provide stimuli to the scientific appetite, without pretending to be exhaustive; [...] to offer opportunities and spaces for the free use by visitor, by providing experiences whose the biggest impact will be on attitudes and feelings" [Merzagora, Rodari 2009, p. 9].

Fig. 10. The detail of the contour line on the wall as a narrative clue in the 'Sala del Gabinetto Ovale' (WREF).
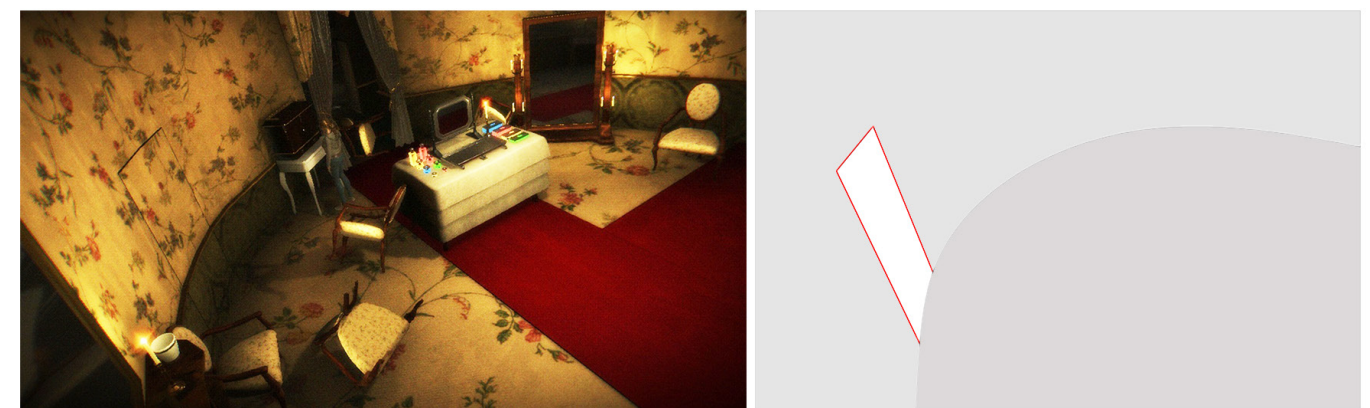

\section{References}

Adams Ernest (20|4). Fundamentals of Game Design. San Francisco: New Riders.

Beale Katy (20I I). Museum At Play: Games, Interaction and Learning. London: MuseumEtc

Bergamo Francesco, Bortot Alessio, Boscaro Cristian et al. (2016). Un percorso fruitivo e conoscitivo degli apparati pittorici del Convento della SS. Trinità dei Monti a Roma. In Disegnarecon, vol. 9, n. 17, pp. 2.1 - 2.9.

Carson Don (2000). Environmental Storytelling: Creating Immersive 3D Worlds Using Lessons Learned From the Theme Park Industry. In Gamasutra, online journal, march 2000, pp. I-4.

Chaplin Heather, Zimmerman Eric (20I3). Manifesto: The 2 I st Century will be defined by Games. In Kotaku, online journal, september 2013.

Di Tore Pio Alfredo, Di Tore Stefano, Mangione Giuseppina Rita, Corona Felice (20/4). Spazio, movimento, prospettiva ed empatia: un prototipo di videogame didattico. In Form@re, Open Journal per la formazione in rete, n.3, vol. I4, pp.43-6I.

Flynn Bernadette (2004). Games as Inhabited Spaces. In The Games Issue, n. I I 0, pp. 52-6I.

Florio Riccardo (2012). Sul disegno. Riflessioni sul disegno di architettura. Roma: Officina.

Galloway Alexander (2006). Gaming. Essays on Algorithmic Culture. Minneapolis: University of Minnesota Press.

Günzel Stephan (2008). The Space-Image. Interactivity and Spatiality of Computer Games. In Günzel Stephan, Liebe Michael, Dieter Mersch (eds.). Philosophy of Computer Games. Potsdam: University Press, pp. $170-189$.

Heath Stephen (1986). Narrative Space. In Rosen Philip. Narrative,Apparatus, Ideology. A Film Theory Reader. New York: Columbia University Press, pp. 379-420.

Higuinen Erwan, Tesson Charles (2002). Éditorial. Chinèphiles et Ludophiles. In Cahiers du Cinèma, n. spec. sett. 2002, p. 5.

Jenkins Henry (2004). Game Design as Narrative Architecture. In Wardrip-Fruin Noah, Harrigan Pat. First Person: New Media as Story, Performance and Game. Cambridge MA:The MIT Press, pp. I I 8- I 30.

Maldonado Tomas (20I5). Reale e Virtuale. Milano: Feltrinelli Editore.

Manovich Lev (2005). Il linguaggio dei nuovi media. Milano: Edizioni Olivares. Collana Nuovi Media. 
McGregor Georgia Leigh (2009). Gamespace. Play \& Architecture in Videogames. Doctoral Thesis of Philosophy. School of Media Arts, University of New South Wales.

Merzagora Matteo, Rodari Paola (2007). La scienza in mostra. I musei scientifici e il pubblico. Milano: Bruno Mondadori.

Murray Janet H. (2006). Toward a cultural theory of gaming. In Popular Communication, n.4, pp. I 85-202.

Prensky Marc (20।3). La mente aumentata. Dai nativi digitali alla saggezza digitale (Trad. di R. Sardi). Trento: Erickson.

Salvarani Renata (2005). Storia locale e valorizzazione del territorio. Dalla ricerca ai progetti. Milano:Vita e pensiero.

Toscano Mario, Gremigni Elena (2008). Introduzione alla sociologia dei beni culturali. Testi Antologici. Firenze: LeLettere.

Viola Fabio (20 17). L'arte del coinvolgimento. Emozioni e stimoli per cambiare il mondo. Firenze: Hoepli.

Wertheim Margaret (1999). The pearly gates of cyberspace:A history of space from Dante to the Internet. Sydney: Doubleday.

\section{Author}

Greta Attademo, Università degli Studi di Napoli “Federico II”, greta.attademo@unina.it

To cite this chapter. Attademo Greta (2020).Videogame e museo. La rappresentazione dello spazio come strumento narrativo per il patrimonio culturale/Videogame and museum. The spatial representation as a narrative strategy for the cultural heritage. Arena A., Arena M., Brandolino R.G., Colistra D. Ginex G., Mediati D., Nucifora S., Raffa P. (a cura di). Connettere. Un disegno per annodare e tessere. Atti del $42^{\circ}$ Convegno Internazionale dei Docenti delle Discipline della Rappresentazione/Connecting. Drawing for weaving relationships. Proceedings of the 42th International Conference of Representation Disciplines Teachers. Milano: FrancoAngeli, pp. 2955-2972 